\title{
Učitelská self-efficacy při práci s dětmi-cizinci v širších souvislostech
}

\author{
Klára Záleská ${ }^{a}$, Alicja Leix ${ }^{\mathrm{b}}$ \\ a Ústav pedagogických věd, Filozofická fakulta, Masarykova univerzita \\ b Nezávislý výzkumník
}

Redakci zasláno 14. 2. 2018 / upravená verze obdržena 18. 7. 2018 / k uveřejnění přijato 18. 7. 2018

\begin{abstract}
Abstrakt: Předkládaná studie se zabývá tématem self-efficacy učitelů českých základních škol v práci s dětmi-cizinci a faktory, které ji ovlivňují. Odpověd' na výzkumnou otázku, jaká je self-efficacy učitelů v této oblasti, jsme získávaly pomocí analýzy polostrukturovaných rozhovorů s učiteli s různě velkou zkušeností s výukou dětícizinců. Výpovědi učitelů jsme analyzovaly mj. s přihlédnutím k základním bodům charakterizujícím chování učitele s vysokým self-efficacy, které jsme sestavily na základě rešerše odborné literatury. Šetření ukázalo řadu faktorů, které hrají roli v tom, jak učitel vnímá svou schopnost práce s dětmi-cizinci, mj. to, že důležitou roli hraje míra zkušeností učitelů s výukou cizinců. Self-efficacy učitelů negativně ovlivňují jejich obavy, a to především obavy z práce s dětmi s nulovou znalostí českého jazyka a s dětmi pocházejícími ze vzdálených kultur. Dotazovaní sami poukazují na možné způsoby, jak zvýšit svou self-efficacy v diskutovaných oblastech. Mezi návrhy jsou napřs. přípravné třídy pro děti-cizince bez znalosti češtiny či posílení vzdělávání učitelů v několika konkrétních oblastech týkajících se praktických aspektů práce v kulturně nehomogenní třídě.
\end{abstract}

Klíčová slova: učitelská self-efficacy, vzdělávání dětí-cizinců, asistent pedagoga, žák-patron, přípravné třídy

Společenský, politický a ekonomický vývoj v celém světě s sebou přináší podstatné demografické změny. Jednotlivé oblasti společnosti, školství nevyjímaje, musí na tyto změny flexibilně reagovat. Česká republika se cizincům otevřela až po sametové revoluci v roce 1989 a je dodnes považována za kulturně homogenní společnost. Žijí zde necelá čtyři procenta cizinců, což je značně pod evropským průměrem, který čítá zhruba 10 \% (United Nations, 2017). Nicméně i v České republice jejich počet stoupá a s ním i počet dětí cizinců $\mathrm{v}$ základních školách ${ }^{1}$. S přihlédnutím k současnému světovému dění lze předpokládat, že se jejich počet bude i nadále zvyšovat.

1 Celkově tvoří děti-cizinci cca $2 \%$ žáků na českých základních školách a vyskytují se především v hlavním městě, dále ve velkých krajských a také př́íhraničních městech. Nejpočetnější 
Ruku v ruce se zvyšujícím se počtem cizinců $\mathrm{v}$ základních školách a díky školské inkluzivní reformě z roku 2016, jsou kladeny na učitele stále vyšší nároky. Český školský zákon staví na rovném přístupu ke vzdělání. Povinná školní docházka se vztahuje na všechny děti, tedy také na děti-cizince ${ }^{2}$ pobývající na území našeho státu déle než devadesát dní (Školský zákon: Zákon č. 561/2004 Sb.) ${ }^{3}$. Učitelé ve vztahu k cizincům získávají roli zprostředkovatele majoritní kultury, jazyka a také prostředníka mezi majoritními dětmi a dětmi-cizinci, mezi školou a rodinou cizincủ. Na nárůst nových povinností a stoupající zodpovědnost pro učitele působící v kulturně heterogenních tř́dách upozorňuje řada výzkumníků (Villegas \& Lukas, 2002; McAllister \& Irvine, 2000; Nieto, 2000; Howard, 1999; Banks, 1996; Bennett, 1995). Jelikož na českých vysokých pedagogických školách jsou povinné předměty zabývající se výukou v kulturně heterogenním prostředí či vzděláváním dětí-cizinců i nadále vzácností nebo novinkou, v terénu lze očekávat nedostatečnou teoretickou průpravu a nedostatečnou praxi mnohých učitelů v oblasti výuky dětí-cizinců. Ta může následně probíhat formou pokus-omyl. Právě v takových situacích nabývá na významu učitelská self-efficacy. Cílem předkládaného výzkumu proto bylo prozkoumat, jak se učitelé cítí v roli vzdělavatelů dětí-cizinců, jaká je jejich self-efficacy při práci s touto cílovou skupinou a co ji ovlivňuje.

skupiny cizinců v základních školách (viz ČSÚ, 2015) tvoří Ukrajinci (4039), Slováci (3775), Vietnamci (3220) a Rusové (1321). Dalšími národnostními skupinami zastoupenými v českých základních školách ve větší míře jsou Bulhaři (385), Mongolové (343), Moldavci (339) a Poláci (302).

2 Pro děti-cizince je v českém kontextu používáno několik označení. $V$ literatuře, strategických dokumentech a legislativě se můžeme setkat s označením dítě/žák-cizinec (SOZE, 2013; MŠMT, 2012), dítě přistěhovalců/cizinců (EURYDICE, 2009), žák s odlišným mateřským jazykem (META, 2014). Děti-cizinci ve vzdělávání dále spadají do kategorie dítě se sociálním znevýhodněním (Jarkovská et al., 2015) a do kategorie dítě se speciálními vzdělávacími potřebami (Školský zákon, Zákon č. 561/2004 Sb.). V tomto textu používáme označení dítěcizinec a myslíme tím jedince, který se do České republiky sám přistěhoval nebo se zde narodil zahraničním rodičům (jde tedy o první a druhou generaci cizinců). Druhou generaci zařazujeme záměrně, jelikož i tyto děti a jejich rodiče se poprvé setkávají intenzivněji s českým jazykem právě až v prostředí školy.

3 Děti a žáci s nedostatečnou znalostí nebo bez dostatečné znalosti vyučovacího jazyka patří podle prŕlohy vyhlášky $27 / 2016$ Sb. mezi žáky se speciálními vzdělávacími potřebami. Ministerstvo školství, mládeže a tělovýchovy vypracovalo novelu školského zákona platnou od září roku 2016, která se týká podpory vzdělávání dětí, žáků a studentů se speciálními vzdělávacími potřebami (\$16). V tomto paragrafu se upustilo od často problematické klasifikace žáků na jednotlivé kategorie dle postižení či znevýhodnění. Žáci jsou v paragrafu nově definováni z hlediska stupně podpory, kterou potřebují. 


\section{Teoretická východiska}

\subsection{Učitel a prítomnost cizinců $v$ běžné třídě}

Než se podíváme na samotný koncept učitelské self-efficacy, pozastavíme se u toho, co pro učitele znamená prrítomnost dětí-cizincủ ve třídě a s čím se kvưli ní potýkají. Každá země řeší otázku vzdělávání dětí-cizinců odlišně a v jiné míře s ohledem na svůj historicko-politický kontext a samozřejmě také s ohledem na celkový počet cizinců v základních školách. ${ }^{4}$ Stejně tak výuka v základních školách jednotlivých zemí vypadá různě; důraz je kladen na různé aspekty, př́ístup učitelů k žákům se liší, učitel má odlišnou míru autority apod.

Nicméně navzdory všem zmíněným rozdílům výsledky zahraničních výzkumů shodně ukazují, že běžné učitelské postupy, jakými učitelé přistupují k majoritním žákům ve své zemi, selhávají při aplikaci ve tř́idách s cizinci (Grant \& Sleeter, 2008; Jenks, Lee, \& Kanpol, 2001; Yeo, 1997; Nieto, 1996; Kanpol \& McLaren, 1995; Sleeter, 1992). Výsledky zároveň naznačují, že učitelé nevědí, jaké jiné postupy by měli při výuce cizinců a v kulturně heterogenních třídách aplikovat. Především učitelé s malou zkušeností s různými kulturami potřebují získat potřebné znalosti a schopnosti, ale také musí přeformulovat svou roli učitele tím, že důležitost diverzity zahrnou do všech svých vzdělávacích rozhodnutí: od zhodnocení připravenosti dítěte $\mathrm{k}$ učení přes vytvoření učebních osnov, výběr výukových materiálů a vyučovacích technik až ke způsobu hodnocení. Tento přístup k výuce se velmi liší od chápání mainstreamové pedagogiky a učebních osnov jako kontextově neutrálních (Kitsantas \& Mason, 2012).

Ze zmíněných důvodů je žádoucí, aby učitelé byli na práci s cizinci v běžné třídě systematicky připravováni (Kitsantas \& Mason, 2012; Banks, 1991, 1996). Podle autorů jsou školy často obecně špatně vybaveny pro přijímání cizinců a nejsou nastavené tak, aby podporovaly cíle multikulturní výchovy, za což nese vinu z velké části právě nepřipravenost učitelů. Gürsoy a Akyniyazov

\footnotetext{
V České republice je (vzhledem k naší kratší zkušenosti s přijímáním cizinců a k jejich stále nízkému procentuálnímu zastoupení $\mathrm{v}$ populaci) téma vzdělávání dětí-cizinců výzkumně stále spíše marginální, i když již existují publikace, které se zaměřují na integraci dětí cizinců do českého prostředí (Kostelecká, Hána, \& Hasman, 2017; Machovcová, 2017); na bariéry při integraci dětí-cizinců (Leix, 2015, 2017; Janská, Průšvicová, \& Čermák, 2011) či na reflexi národní integrační politiky ve vztahu k dětem-cizincům (Jarkovská et al., 2015; Kostelecká et al., 2015; Bačáková, 2012 apod.).
} 
(2016) či Jenks, Lee a Kanpol (2001) apelují na potřebu zlepšit př́stup učitelů k odlišnosti jako takové. Podle nich učitelům často chybí ochota ke změně, kterou výuka ve tř́dě s cizinci vyžaduje. Nedostatečná průprava učitelů způsobuje v praxi jejich časté obavy a nedůvěru v sebe sama při výuce dětí-cizinců. Výzkum Howarda (1999) ukázal, že obavy učitelů základních škol z výuky dětí-cizinců vyvěrají často z nejistoty, zda a jak ve výuce reagovat na etnicitu a kulturní rozdílnost svých žáků. Autor zjistil, že za příčinami obav učitelů často stojí jejich rasové předsudky a úzkost z nedostatku znalostí o etnické a kulturní rozmanitosti. $\mathrm{K}$ podobným závěrům směřuje studie $\mathrm{z}$ českého prostředí (Leix, 2015). Kromě toho Howard (1999) upozorňuje, že si učitelé a studenti učitelství myslí, že pedagogická školení o kulturním povědomí a rozhovory týkající se rasové, etnické a kulturní rozmanitosti s žáky nejsou dostačující pro změnu výuky v kulturně heterogenních třídách.

\subsection{Učitelská self-efficacy}

Self-efficacy může být do českého prostředí přeložena jako vnímaná vlastní zdatnost (Gavora \& Majerčíková, 2012; Wiegerová et al., 2012; Zulkosky, 2009), vnímaná osobní/vlastní účinnost (Hoskovcová, 2005; Hrbáčková \& Šafránková, 2015) či jako důvěra ve vlastní schopnosti (Urbánek \& Čermák, 1997). Koncept byl vytvořený Albertem Bandurou v rámci jeho sociálně-kognitivní teorie (Bandura, 1997). Jedná se především o přesvědčení lidí o vlastních schopnostech organizovat a následně vykonávat jistou činnost s cílem dosáhnout konkrétního výkonu (Bandura, 1986). Bandura (2005) uvádí, že self-efficacy ovlivňuje to, jak lidé myslí, jak se chovají a jak sami sebe motivují. Budeme-li hovořit o pocitech, nízká míra self-efficacy bývá provázena stresem, úzkostí a bezmocí. Jedinci s nízkou self-efficacy mají taktéž nízké sebevědomí ${ }^{5}$ a bývají pesimističtější, co se týče vlastních úspěchům a osobního rozvoje (Bandura, 1997). Vysoká míra self-efficacy má naopak vliv na tvorbu optimistických postojů, resp. silný pocit self-efficacy zvyšuje výkony lidí a duševní pohodu (Hoskovcová, 2005; Hrbáčková \& Šafránková, 2015). Self-efficacy ovlivňuje výběr aktivit a její míra může zvýšit nebo brzdit motivaci. To se odráží v tom, jak moc úsilí jedinec vynaloží k tomu, aby dosáhl vytyčeného cíle, a také v tom, jak dlouho vydrží čelit překážkám, než své úsilí vzdá (Bandura, 1995). Jinak řečeno, lidé s vysokou mírou self-efficacy se nevyhýbají obtížným úkolům, přijímají je naopak jako výzvy. Vzhledem k charakteristice konceptu figuruje self-efficacy ve všech aktivitách člověka, učitelskou činnost nevyjímaje (Wiegerová et al., 2012).

Jedinec, který má pozitivní sebehodnocení, vyšší sebedůvěru a zdravé sebevědomí, má pevný základ pro svůj psychický vývoj a vývoj své self-efficacy (Bandura, 1997). 
Učitelská self-efficacy je v zahraniční literatuře chápána jako víra ve vlastní schopnosti organizovat a vést výuku s cílem splnit specifický úkol v konkrétním kontextu (Tschannen-Moran \& Woolfolk Hoy, 2001). Jedná se tak o to, jak se učitelé v určitých situacích zachovají, nikoli o to, čeho a proč již v minulosti dosáhli (Goddard \& Woolfolk Hoy, 2000). Učitelská self-efficacy sestává ze dvou částí: profesní učitelské self-efficacy ${ }^{6}$ a osobní učitelské self-efficacy ${ }^{7}$. Učitelská self-efficacy tak zahrnuje různé oblasti, např. schopnost vysvětlit látku, klást vhodné otázky, nakládat s časem, udržet disciplínu ve třídě, spolupracovat s rodiči nebo spolupracovat s kolegy. V českém prostředí můžeme nabídnout definici učitelské self-efficacy Gavory a Majerčíkové (2012), kteří ji chápou jako přesvědčení o svých schopnostech ve svém povolání něčeho dosáhnout bez ohledu na své skutečné předpoklady či kompetence. Gavora (2010) upozorňuje, že je nutné neplést si pojem učitelské self-efficacy s učitelskými kompetencemi, které jsou vztahovány především k učitelovým profesionálním znalostem a dovednostem. Učitelská self-efficacy je širší pojem. Vysoká míra učitelské self-efficacy v podstatě učiteli umožňuje efektivně využít své profesionální znalosti a dovednosti. Učitelskou self-efficacy tak Gavora chápe jako silné samoregulační vlastnosti učitele, které umožňují využít jeho potenciálu k posílení učení žáků. S vysokou mírou učitelské self-efficacy se tak spojuje řada pozitivních následkư⿴囗.

Shrneme-li výsledky výzkumů učitelské self-efficacy na různých typech a stupních škol (Gavora \& Majerčíková, 2012; Wiegerová et al., 2012; Ross \& Bruce, 2007; Henson, 2001; Tschannen-Moran \& Woolfolk Hoy, 2001), můžeme říci, že učitel s vysokou mírou self-efficacy se vyznačuje tím, že ve srovnání s učitelem s nízkou self-efficacy: (1) častěji volí různé vyučovací postupy, (2) lépe odolává stresu, (3) má tendenci dávat žákům více problémových úloh

6 Týká se situací, kdy se od učitele očekává, že pomůže studentům naučit se látku, i když mají různé studijní předpoklady (Bandura, 1997). Učitelé s vysokou profesní učitelskou selfefficacy jsou přesvědčeni, že jsou schopni pozitivně ovlivnit výkon žáka. Vybírají si náročné aktivity a snaží se čelit překážkám (jako jsou předpoklady a schopnosti žáků či jejich domácí zázemí). Takoví učitelé mají tendenci věřit, že všichni žáci jsou schopni se učit, pokud jim jsou poskytnuty vhodné podmínky pro učení (Tschannen-Moran \& Woolfolk Hoy, 2001).

7 Týká se vlastního hodnocení vyučovacích schopností učitele. Výzkumy ukazují, že volba výukových strategií a řízení třídy (včetně nakládání s časem a způsobu kladení otázek) je ovlivňována osobní učitelskou self-efficacy (Gibson \& Dembo, 1984). Učitelé, kteří pochybují o svých schopnostech a zaměřují se na své nedostatky, mohou mít negativní vliv na motivaci svých žáků stejně tak jako na vztah žáků ke školním pravidlům. Když si učitel nedůvěřuje, klesá celková efektivita jeho výuky (Ashton \& Webb, 1986).

8 Například dobré studijní výsledky jejich žáků (Anthony \& Kritsonis, 2007), motivovanost žáků (Nolen et al., 2007), zodpovědnost žáků za vlastní učení (Darling-Hammond et al., 2002) či spokojenost s vlastními výkony (Carara et al., 2006). 
než takových, ve kterých uplatňují pouhou reprodukci vědomostí, (4) věnuje více času tomu, aby dovedl žáka ke správným odpovědím na otázky, (5) častěji používá skupinovou práci, (6) více se věnuje slabším žákům, (7) aktivně rozvijí svůj vztah k rodině žáka a je schopen ji zapojit do společných aktivit. Poslední, sedmá, charakteristika učitele s vysokou self-efficacy nepochází přímo ze závěrů výše zmíněných autorů. Přidaly jsme ji proto, že spolupráci $\mathrm{s}$ rodiči považujeme $\mathrm{v}$ př́ípadě práce $\mathrm{s}$ dětmi-cizinci za obzvlášt' důležitou. Souhlasíme s Gavorou a Majerčíkovou (2012) v tom, že samotným vyučováním činnost učitele nekončí a učitelská self-efficacy se promítá do oblasti spolupráce s rodiči tím spíše, když se jedná o cizince.

\section{Učitelská self-efficacy při práci s dětmi-cizinci}

$\mathrm{V}$ českém prostředí zatím tématu self-efficacy při práci s dětmi-cizinci nebyla věnovaná výzkumná pozornost. Uvádíme proto základní přehled o tom, jak se k problematice staví zahraniční výzkumníci. Ke konceptu seIf-efficacy učitelů pracujících s dětmi-cizinci je k dispozici několik kvantitativních šetření používajících především dotazník Teacher self-efficacy scale (Gürsoy \& Akyniyazov, 2016) či Teachers' sense of efficacy scale (Silverman, 2008) vztažené na multikulturní školní prostředí. Používá se také koncept multikulturní self-efficacy učitelů (Yildirim \& Tezci, 2016; Jefferson, 2013; Silverman, 2008; Guyton \& Wesche, 2005). Hlavním zjištěním výzkumů je, že učitelé obecně postrádají povědomí a potřebné znalosti o rase a etnicitě, což je předpokladem vysoké míry multikulturní self-efficacy (Titone, 1998). Autoři toto zjištění považují za problematické, protože nízká multikulturní self-efficacy učitelů může limitovat pedagogické postupy, které učitelé ve své výuce volí a které mohou být užitečné a efektivní s ohledem na diverzitu žáků, se kterými pracují.

Děti-cizinci jsou skupinou, která se cítí být kvůli své etnické a jazykové odlišnosti nejistá. Aby se jim ve škole dařilo, samy potřebují silný pocit self-efficacy, což můžeme u této skupiny chápat jako důvěru ve své schopnosti se záměrem dosáhnout vzdělávacích cílů (Guskey, 1988). Potřebují proto učitele, kteř́ jim pomohou stavět víru v sebe sama. Jinými slovy, potřebují učitele, kteří mají vysokou míru self-efficacy (Sleeter, 2008). Podle Watsonové (1991) učitelé s vysokou self-efficacy zvyšují angažovanost a akademickou výkonnost žáků etnicky a jazykově různorodých. Takoví učitelé podle Watsonové lépe řeší konfliktní situace žáků, což potvrzují také výzkumy Klassena (2004) či Peguera a Bondyho (2011). Výzkum Adamsové a Bellové (2016) potvrdil silnou korelaci mezi mírou self-efficacy učitele a jeho žáků, a to i těch řadících 
se do znevýhodněných skupin, mimo jiné dětí-cizinců, které často při příchodu do nové školy postrádají motivaci.

Shrneme-li nálezy výzkumníků, můžeme říci, že učitelé s vysokou self-efficacy jsou přesvědčenější o své schopnosti překonávat překážky ve vzdělávání dětí-cizinců a uchylují se k většímu úsilí pomoci svým žákům dosáhnout maximálního školního úspěchu. Takoví učitelé zvyšují self-efficacy svých žáků, kteří jsou pak více angažovaní, soustředění, dávají si vyšší cíle a usilovně se snaží, aby jich dosáhli.

\section{Metodologie}

Cílem studie je prozkoumat současný stav učitelské self-efficacy (a její souvislosti) při práci s dětmi-cizinci a zodpovědět výzkumnou otázku: Jaká je self-efficacy učitelů pracujících s dětmi-cizinci? Na koncept self-efficacy pro účely tohoto textu nahlížíme jako na víru učitele ve vlastní schopnosti při výuce dětí-cizinců.

Odpověd' na výzkumnou otázku hledáme cestou kvalitativní analýzy rozhovorů s učiteli základních škol. Výsledky ve formě ukázek konkrétních postupů uplatňovaných učiteli v jednotlivých výukových situacích komentujeme za využití charakteristik učitelů s vysokou mírou self-efficacy tak, jak je uvádí odborná literatura.

\subsection{Vzorek}

Pro výběr respondentů jsme použily jednu z metod kvalitativního výzkumu, a sice metodu cíleného výběru. Ten vychází z kritického zvážení parametrů populace a soustředí se na pečlivě vybrané prostředí a jednotlivce, kde je největší pravděpodobnost výskytu sledovaných jevů (Silverman, 2005; Stake, 2005). Často se hovoří o tom, že péče o děti-cizince bývá odlišná ve školách s malým a s velkým počtem cizinců. Potvrzují to také provedené výzkumy (např. Kitsantas \& Mason, 2012; Jenks, Lee, \& Kanpol, 2001), které uvádí, že oblasti s malým počtem cizinců a malou kulturní a rasovou diverzitou ve školách jsou obvykle hưře až špatně vybaveny $k$ tomu, aby poskytly kvalitní vzdělání dětem-cizincům. $Z$ toho důvodu naším kritériem výběru respondentů bylo najít učitele s různou mírou zkušenosti s výukou dětí-cizincủ. Šetření proběhlo $s$ učiteli ze dvou základních škol v hlavním městě (škola A s 20 \% cizinců, škola B s $6 \%$ cizinců) a v jedné škole ve větším krajském městě (škola C s $17 \%$ cizinců). Celkem bylo sesbíráno 12 rozhovorů 
s 12 učiteli. Kromě vyššího počtu dětí-cizinců se jednalo o školy běžné, státní, nevyznačující se žádnými extrémy, jako jsou špatné výsledky žákủ, problémovost školy atd. Tím jsme chtěly docílit náhledu do běžné reality českých škol.

Tabulka 1

Charakteristika respondentů

\begin{tabular}{|c|c|c|c|c|}
\hline Jméno & Škola ${ }^{10}$ & Pozice & Zkušenost s cizinci $^{8}$ & Délka učitelské praxe \\
\hline Marie & $\mathrm{A}$ & $\begin{array}{l}\text { třídní 1. třídy } \\
\text { kroužek ČJ pro cizince }\end{array}$ & velká & 2 roky \\
\hline Standa & $\mathrm{A}$ & třídní 4. třídy & velká & 10 let \\
\hline Pavla & $\mathrm{B}$ & $\begin{array}{l}\text { třídní 3. třídy } \\
\text { ČJ pro cizince }\end{array}$ & střední & 30 let \\
\hline Karla & $\mathrm{B}$ & $\begin{array}{l}\text { třídní } 2 \text {. třídy } \\
\text { ČJ pro cizince }\end{array}$ & střední & 4 roky \\
\hline Sabina & B & třídní přípravné třídy & velká & 21 let \\
\hline Martina & $\mathrm{B}$ & $\begin{array}{l}\text { třídní 4. třídy } \\
\text { ČJ pro cizince }\end{array}$ & malá & 35 let \\
\hline Sylva & B & třídní 5. třídy & malá & 20 let \\
\hline Tamara & $\mathrm{C}$ & $\begin{array}{l}\text { asistentka } \\
\text { ČJ pro cizince }\end{array}$ & velká & 8 let \\
\hline Petra & $\mathrm{C}$ & učitelka ČJ pro cizince & velká & 7 let \\
\hline Simon & $\mathrm{C}$ & třídní 1. třídy & $\begin{array}{l}\text { malá (1žák bez } \\
\text { znalosti ČJ) }\end{array}$ & 25 let \\
\hline Helena & $\mathrm{C}$ & třídní 1. třídy & $\begin{array}{l}\text { malá (1žák bez } \\
\text { znalosti ČJ) }\end{array}$ & 25 let \\
\hline Eva & $\mathrm{C}$ & třídní 2. třídy & velká & 41 let \\
\hline
\end{tabular}

\subsection{Výzkumný design}

Jelikož záměrem předložené studie bylo porozumět doposud nepř́liš zkoumanému jevu, zvolily jsme metodologii kvalitativního výzkumu (Creswell, 2014; Švaříček \& Šed’ová et al., 2007; Hendl, 2005; Strauss \& Corbinová, 1999). Design studie je explorační, protože cílem je hloubkové prozkoumání doposud jen málo prostudovaného fenoménu (Cuthill, 2002; Streb, 2002). Shodně se zásadami explorační studie si klademe za cíl představit současnou situaci v oblasti self-efficacy učitelů v práci s dětmi-cizinci; tento typ designu

9 Malá zkušenost = výuka pouze českých dětí nebo dětí-cizinců, které ale již česky hovořily, nebo 1-5 jedinců, kteří česky neuměli dobře; střední zkušenost = 5-10 cizinců bez znalosti češtiny; velká zkušenost = více než deset cizinců bez znalosti češtiny.

10 Dále v textu označovány jako ŠA, ŠB a ŠC. 
navíc pomáhá stanovit priority pro tvůrce politik (Witter, 2013). Výsledky tak mohou být využitelné nejen pro akademickou sféru, ale mohou posloužit rovněž tvůrcům vzdělávací politky. Máme na paměti i hlavní nevýhodu exploračních studií, kterou je malý výzkumný vzorek, kvůli němuž nelze výsledky zobecňovat na celou populaci.

\subsection{Sběr a analýza dat}

Vzhledem $\mathrm{k}$ povaze výzkumné otázky jsme postupovaly metodou polostrukturovaných rozhovorů. Celkem bylo v akademickém roce 2015/2016 a 2016/2017 pořízeno 12 rozhovorů ${ }^{11}$. Schéma rozhovoru obsahovalo třicet otevřených otázek, které se týkaly podpory adaptace dětí-cizincủ obecně a dotýkaly se sedmi oblastí charakteristik učitele s vysokou self-efficacy představených výše. Každý rozhovor trval zhruba šedesát minut. Respondentům byl vysvětlen cíl výzkumu a byli ubezpečeni o anonymizaci dat; získali přezdívky a byla anonymizovaná i další data ve výpovědích, která by mohla vést k odhalení identity nejen jejich, ale také dětí, rodičů či školy. Všechny rozhovory byly se svolením respondentů nahrány na diktafon a posléze přepsány do textového dokumentu. Přepis každého rozhovoru činil průměrně 10 stran, celkový datový korpus čítá 150 stran. V rámci transkripce jsme výpovědi ponechávaly v originální formě, bez stylistických či jiných úprav. V takové formě také výpovědi uvádíme. Všechny přepsané rozhovory byly nahrány do programu ATLAS.ti, ve kterém byly podrobeny analýze.

Odpovědi na položenou otázku jsme získávaly dvěma způsoby. Prvním z nich bylo tematické (deduktivní) kódovaní (Merten, 1996; Boyatzis, 1998; Heading \& Traynor, 2005; Komori, nedatováno), v němž jsme kategorie zformulovaly před analýzou dat na základě předchozích výzkumů. Kategoriemi pro nás bylo sedm okruhů (prezentovaných výše) charakterizujících učitele s vysokou self-efficacy v práci s dětmi-cizinci. Chtěly jsme ověřit, do jaké míry se námi získaná data překrývají s teoretickými koncepty. Druhý způsob byl opačný; vyšly jsme nikoliv z teorie, ale přímo z dat a pomocí otevřeného

11 Rozhovory byly sebrané primárně kúčelům disertační práce jedné z autorek na téma podpory adaptace dětí-cizinců do základních škol. S respondenty se během rozhovorů podařilo navázat natolik dobrý vztah, že získaná data jsou informačně velmi bohatá a pokrývají širokou škálu témat spojených s prací s dětmi-cizinci. Self-efficacy dotazovaných a jeho širší souvislosti se při prvotních analýzách ukázaly být jako jedno z hlavních témat, která se v rozhovorech objevovala, proto jsme se rozhodly věnovat tomuto tématu samostatný článek. Jedná se tak o v kvalitativní analýze často popisovanou možnost opakovaného využití kvalitativních dat pro jejich bohatost (např. Moore, 2007). 
kódování (Švaříček \& Šed'ová et al., 2007) jsme zachycovaly další důležitá témata související s učitelskou self-efficacy, která učitelée ${ }^{12}$ zmiňovali. Kombinací postupů (concept-driven a data-driven) jsme chtěly docílit maximálního vytěžení dat vzhledem ke zkoumané oblasti.

\section{Výsledky}

Výsledky prezentujeme ve dvou částech. První část obsahuje výsledky analýzy samotného vnímání osobní zdatnosti učitelů, které konfrontujeme se sedmi kategoriemi popisujícími učitele s vysokou self-efficacy. Tato část nese název Když učitel ví, že na to má... Druhá část nese název Když učitele při výuce cizinců doprovází všudypř́tomné obavy..., jelikož právě obavy učitelů z výuky dětí-cizinců se ukázaly být v jejich komentářích zásadní. Nachází se zde tři hlavní témata: výuka dětí-cizinců s nulovou znalostí češtiny; kontakt s cizinci ze vzdálených kultur a nedostatečné systémové znalosti o vzdělávání dětí-cizinců. Pokud se jedná o formu prezentace výsledků, postupujeme dle jednotlivých kategorií / tematických okruhů, u každé z prezentovaných kategorií stručně vysvětlujeme její obsah a ilustrujeme ji konkrétními výpověd'mi učitelů. ${ }^{13}$

\subsection{Když učitel ví, že na to má...}

Volba různorodých vyučovacích postupů: hledání cesty, jak to jde

Učitel s vysokou mírou self-efficacy se vyznačuje tím, že při výuce střídá různorodé postupy. Ve třídě s cizinci jsou právě různé způsoby, jak vysvětlit látku, pokud žák nerozumí, zásadní. Někteří dotazovaní učitelé to vnímají jako překážku, jiní však (na př́́klad Petra, ŠC) jako příjemnou výzvu: „Umět vysvětlit cizincovi českou gramatiku deseti různými způsoby mi přijde jako strašně těžký úkol, když on pořád nechápe. Nebo vysvětlovat význam slov, popisovat a hledat cesty, aby pochopil, co znamená to a jak funguje ono, to je pro mě obrovská výzva a to mě na tom strašně baví." Souhlasně se vyjadřovala také Sabina (ŠB), která tvrdí, že práce s cizinci není prací pro každého právě proto, že po učitelích vyžaduje vymýšlení neustále nových způsobů,

Takto vznikly tři hlavní kategorie: výuka cizinců s nulovou znalostí češtiny; děti-cizinci ze vzdálených kultur a nedostatečné znalosti o výuce dětí-cizinců.

13 Což odpovídá jednomu z typických postupů kvalitativní obsahové analýzy (QCA), podrobně např. v Qualitative content analysis in practice (Schreier, 2012). Hojným používáním originálních výpovědí a minimální interpretací výroků dotazovaných učitelů jsme chtěly zmírnit vliv na čtenáře a ponechat mu v maximální možné míře možnost udělat si vlastní názor na citované výpovědi učitelů z praxe. 
jak s dětmi-cizinci pracovat. Učitelé se shodli v tom, že při výuce dětí-cizinců musí mít učitel chut' čelit výzvám. Problematické na tomto zjištění je, že si učitelé nevybírají složení své třídy, cizinec se může objevit v kterékoliv a může se setkat s učiteli, kteří nejsou nastaveni tak, jak popisují uvedené ukázky. Přesto musí najít cestu, jak s cizincem pracovat.

Učitelé obecně chválí individuální hodiny s cizinci, v nichž mohou vymýšlet a používat různé metody a způsoby, které kvůli omezenému času a ostatním dětem ve třídě nemohou použít při běžné výuce. Dokládá to tvrzení Pavly (ŠB): „Je skvělé, když máme individuálku, používáme obrázkový knížky, to dítě se vás zeptá, čemu nerozumí. Máte víc času a rozhodně tohle je nejlepší mít jedno dítě na jednoho učitele. Protože tomu dítěti můžete dát cokoliv." Individuální doučování dětí-cizinců se ukázalo jako řešení, při kterém si učitelé věří, protože jsou s dítětem sami a mohou si dovolit zkoušet použít rủzné materiály a způsoby výuky.

\section{Psychická odolnost a trpělivost učitelů jsou klíčové}

Literatura uvádí, že míra učitelské self-efficacy je ovlivněna tím, jak jsou učitelé odolní vůči stresu a jak jsou trpěliví. Práce s dětmi-cizinci, kdy s nimi učitelé často nemají žádný společný jazyk, pro učitele znamená mnohem větší psychický tlak a požadavek na jejich trpělivost.

Snad i kvůli tomu, že dotazovaní učitelé nedostali žádnou teoretickou průpravu toho, jak pracovat s dětmi-cizinci v rámci svého studia na vysoké škole, provází jejich kontakt s nimi často stres. Z učitelských výpovědí jsme proto zjištovaly, co vnímají jako náročné při práci s dětmi-cizinci. Všichni respondenti si posteskli nad celkovou náročností výuky v kulturně heterogenní tř́idě a tlakem, který na ně taková výuka celkově vyvíjí:

Je to prostě náročnější. Ne jenom na přípravu učitele, ale taky právě na to, že ten učitel musí víc jako hrát. Nebát se to předvést, že jdu, že sedím nebo že se směju, umět si poradit, co lze předvést, co lze ukázat - na sobě, bez pomůcek, nebát se toho... Třeba i pozastavit plán, je-li to třeba, a ty dané stěžejní pojmy fakt to dítě naučit hned ze začátku. (Marie, ŠA)

Výpověd' upozorňuje na to, že práce v kulturně heterogenní třídě je časově náročná také na přípravu učitelů a často je fyzicky vyčerpávající, vyžaduje proto od učitelů silnou vůli a přesvědčení, že se jejich úsilí dočká úspěchu. I ostatní učitelé zmiňovali, že při práci s cizinci jde především o trpělivost učitele: „Kdybych na ně spustila, že teda: Dyt' už jsme to dělali sto padesátkrát! 
No, tak to bych z nich nedostala už ani slovo, takže trpělivost, člověk se musí obrnit trpělivostí, to není úplně lehké." (Petra, ŠC).

Na následujícím příkladu je názorně vidět odhodlání učitelky v práci s problémovým žákem. Nevzdala se ani po několika neúspěších a věřila, že se její snaha setká s úspěchem. Až po individuálních hodinách se zlepšilo chlapcovo chování i prospěch, jak uvedla Martina (ŠC):

Kvůli němu jsem si připravila hodiny, kde jsem si ř́kala, tady má možnost se zapojit, připravovala jsem mu extra materiály. On to zmuchlal, hodil to na zem a nebudu to dělat. Takže on opravdu stál na zadních. A mně to dost vadilo, takže jsem šla za tou třídní učitelkou a říkám: Hele, nezlob se, ale takhle to dál nejde. A řekla jsem si NE, já to nevzdám, já jsem tady šéf, ty prostě budeš dělat, co jsem řekla, a hotovo. Prostě neexistuje, školní docházka je povinná, ty se musíš vzdělávat. Tvoje rodina tu chce žít, takže ty prostě budeš pracovat. Takže jsme se začali scházet sami po škole a výsledky jsou úžasný.

Tendence dávat žákům více problémových úloh a cizincům tvořit ulehčené úlohy

Výzkumy uvádějí, že učitelé s vysokým self-efficacy mají tendenci vytvářet pro žáky náročnější úlohy (Wiegerová et al., 2012; Ross \& Bruce, 2007; Henson, 2001; Tschannen-Moran \& Woolfolk Hoy, 2001). V našem případě by se vlastně mělo jednat o opak - učitelé $s$ vysokou self-efficacy by měli mít tendenci dětem-cizincům tvořit úlohy „na míru“, tj. na začátku především lehčí a volit pro ně vhodnější materiály. Ovšem tvorba jakýchkoli nových materiálů znamená pro učitele další zátěž. Učitelé v našem vzorku obecně sdělovali, že si jsou vědomi důležitosti toho, tvořit cizincům speciální úlohy a jiné zadání při výuce, nicméně upozorňují především na časovou náročnost, kterou tvorba více příprav a extra úloh pro cizince obnáší. $\mathrm{V}$ praxi se proto $\mathrm{k}$ takovému jednání učitelé uchylují jen zř́ídka: „Co zvládnou, to je nechám dělat. Co vím, že nezvládnou, tak jim nedávám a můžou si kreslit nebo psát." (Sylva, ŠB). Takový př́ístup k dětem-cizincům je možný kvůli možnosti neklasifikovat nově příchozího z předmětů, ve kterých je znalost českého jazyka klíčová.

Často se hovoří o tom, že materiálů pro výuku cizinců je v českém prostředí nedostatek. Dotazovaní učitelé toto tvrzení zpřesnili a uváděli, že materiálů pro výuku češtiny dětí-cizinců s nulovou znalostí jazyka, již existuje dost. Chybí ale materiály pro mírně pokročilou úroveň, jak dokládá například výpověd' Heleny (ŠC): „Je toho už vlastně docela dost, ale ono je to pořád 
dokola - počasí, zelenina, zvířata. Potom ta další pokročilost už je horší, tam není vůbec nic." Se stejným problémem se učitelé potýkají i v ostatních předmětech. Naprosto totiž chybí učebnice a další materiály uzpůsobené jednoduššímu jazyku cizinců. Učitelé si často stěžují, že např́íklad v dějepise, zeměpise a přírodopise používají slovní zásobu, které děti-cizinci, kteří se teprve česky učí, nemohou porozumět: „Pro předměty jako přírodověda, fyzika, zeměpis nebo dějepis, to nic pro ty cizince lehčího není. Jak já jí mám vysvětlit centrální nervovou soustavu, když ona nerozumí ani slovu člověk." (Tamara, ŠC). Všichni učitelé uvedli, že cestou, jak ulehčit dětem-cizincům probíranou látku v ostatních předmětech, je mít svůj vlastní arzenál obrázků a sázet na vizuální pomoc, avšak upozorňují na to, že samožrejmě ne vše se dá vysvětlit pouhým ukázáním obrázku a záleží na učiteli, zda obětuje svůj čas takové extra př́ípravě.

Čas věnovaný tomu, aby učitel dovedl žáka-cizince ke správným odpovědím na otázky

Výzkumy ukazují, že čím vyšší míru self-efficacy učitel vykazuje, tím více času věnuje tomu, aby žáky dovedl ke správným odpovědím (Ross \& Bruce, 2007; Henson, 2001; Tschannen-Moran \& Woolfolk Hoy, 2001). Jinými slovy nechává žáky více přemýšlet, než jim řekne správnou odpověd.

Dotazovaní učitelé si posteskli, že by rádi věnovali více času tomu, aby se každé dítě mohlo v průběhu vyučování vyjádřit. Nepřítelem jim však je vysoký počet dětí ve tř́idě a čas, který by ztratili na probírání dané látky. Proto většina učitelů uvedla, že když je tlačí čas, záměrně nevyvolávají děti-cizince, protože by se zdrželi ještě víc:

Aby vám každý něco řekl, tak vám ta hodina na to nestačí. Ono se to na těch dětech určitě podepíše, protože nemají čas se vyjadřovat. Hlavně ti cizinci, že jo, ti než začnou mluvit, už je půl minuty pryč a už vyvoláváte někoho jinýho, protože jde o čas, který vám potom chybí. A když se vám ve třicetičlenné tř́dě sejde šest cizinců, tak trpí ten jejich jazyk, samozřejmě, ale jinak to nejde. Eva ( $\breve{C}$ )

Jedním z řešení nedostatku času v běžných hodinách může být zavedení pravidelných třídnických hodin, při nichž se mohou vyjádřit všechny děti:

Já si s těma dětma sednu do kroužku a povídáme si, co bylo o víkendu, aby měl každý prostor pro to se nějak projevit, aby měl nějakou svoji větičku. Myslím si, že je to důležitý, aby se nebály mezi sebou mluvit, aby se poslouchaly navzájem. Cizinců se ptám třeba, jak se cítí v téhleté naší společnosti. Simon ( $\breve{S} C)$ 
Učitelé, kteří mají k dispozici asistentku, ji často využívají právě ve chvílích, kdy cítí, že by bylo potřeba věnovat se dětem-cizincům více. Poprosí asistentku, která bud' v rámci nebo nad rámec výuky s daným cizincem látku či opravu domácího úkolu nebo testu individuálně a detailně probere:

Já třeba poprosím asistentku, že jsme psali testík, já jsem ji to nechala normálně napsat, tu holčičku. No a pak jsem to dala asistentce, ony si nad tím sedly spolu, větu po větě... A probraly to pěkně individuálně podrobně jo, na to já v tý tř́dě čas nemám. (Helena, ŠC)

Největším nepřítelem učitelů je v tomto ohledu (kromě obecně zvyšující se diverzity ve třídách) vysoký počet dětí ve třídě, který učiteli téměř znemožňuje časově náročný individuální přístup.

\section{Používání skupinové práce a stř́íání aktivit}

Učitelé s vyšší mírou self-efficacy podle výzkumů častěji praktikují skupinové práce a stř́idají častěji aktivity ve výuce než učitelé s nízkou self-efficacy (Ross \& Bruce, 2007; Henson, 2001; Tschannen-Moran \& Woolfolk Hoy, 2001).

Učitelé z řad respondentů uváděli, že se ve svých hodinách snaží zařazovat i skupinovou práci a střídat aktivity, aby neztratili soustředění svých žáků. Ovšem jakákoliv forma skupinové práce v heterogenní tř́́dě, v níž část žáků rozumí podstatně méně, vyžaduje minimálně tvorbu více skupin. Většina učitelů by si dovedla představit, že si např. na část výuky vezme stranou skupinu cizinců a zbytku tř́́dy dá jinou práci, avšak všichni si posteskli na náročnost realizace takové výuky ve velkém počtu dětí ve třídě. Řada $\mathrm{z}$ nich by proto ocenila přítomnost asistenta ve třídě:

Když by tady byla asistentka, tak já bych si mohla vzít třeba skupinku cizinců a mohla bych s nima dělat něco a ona by mohla koukat na ty ostatní děti, který nepotřebujou rozšiřovat slovní zásobu a měly by jinej úkol. Ono to takhle nejde, protože i když ty děti jsou fakt skvělý, tak jsou zvědaví a koukaj tam, co já s nima dělám, nebo potřebujou poradit, něco nerozumí. Já jim ř́íám, klidně se zeptejte, desetkrát stokrát, klidně to přeženu, zeptejte se, než abyste to udělali špatně. Já vám to budu vysvětlovat, dokud to nepochopíte. Jo, a to právě moc nejde, když jsem sama. Já bych si vzala 4 děti, procvičovali bysme slovní zásobu, ona by nejen mohla dohlídnout i na ty ostatní a vysvětlit jim to. No a to já nemůžu, a tím pádem šidím jak ty cizince, tak ty ostatní. (Sabina, ŠB) 
Protože ne všichni učitelé mohou využít asistenta pedagoga, ve vztahu k cizincům se jim spíše než skupinová práce osvědčuje role tzv. patrona, kterého učitelé pečlivě vybírají ze zbytku dětí ve své třídě: „Ona s pochopením textu nemá problémy, ale třeba ted' děláme těžší slova a doplňování písmem, tak Frantík je připraven jí pomoct. On je takový fajn, má vyřídilku a nebojí se, proto jsem asi i vybral jeho. Tak ona, když něčemu nerozumí, tak se Frantíka zeptá a on jí to vysvětlí." (Simon, ŠC). Role patrona učitelům dává pocit, že je o cizince postaráno a může tak zařazovat více různých aktivit vhodných pro celou tř́du, v rámci kterých by si žák-cizinec bez pomoci neporadil.

\section{Intenzivní věnování se cizincům}

Lze předpokládat, že učitelé mající nízkou míru self-efficacy se nebudou výukou cizinců ve své třídě nijak intenzivněji zabývat. Dotazovaní učitelé uváděli, že by se cizincům věnovali rádi více, ale opět naráží spíše než na nedostatek své self-efficacy na vysoký počet dětí ve tř́idě, který je v tomto ohledu překážkou. Učitelé se shodují na tom, že aby se mohli intenzivněji věnovat cizincům a slabším žákům, potřebovali by mít ve třídě celkově nižší počet dětí. Řada učitelů se proto věnuje dětem-cizincům nad rámec běžného vyučování v podobě tak zvaných intervencí, doučování či kroužků.

Učitelé, kteří se cizincům věnují intenzivněji, k nim mají velmi empatický přístup a snaží se jim pomoci z následujícího důvodu: „My se jim snažíme pomoct s českou gramatikou, s látkou, kterou potřebujou do školy. Je škoda, aby propadali jenom proto, že jsou cizinci." (Karla, ŠC). Podle slov dotazovaných učitelů však existují kantoři, kteří tak empatičtí nejsou a kteří po cizincích chtějí, aby měli znalosti odpovídající stupni školní docházky určenému pro české děti. S takovými se potom učitelé, kteří se cizincům věnují více, dostávají do názorového střetu, jak dokládá výpověd' Petry (ŠC):

Ona řada učitelů má totiž tu tendenci, aby se jima nemuseli zabývat, tak at’ tam sedí, hlavně at' neotravuje... Jako mě to úplně drásá tohle, já bych takovejhle přístup nevymyslela, natož abych ho praktikovala. Jako někdo si říká, příští rok tam žádnej cizinec nebude... Ale on může přijít, že jo, a tímhle tím se utěšovat. Nebo prostě jim neuleví. Tak on neví, co je pán, hrad, muž, stroj... Nezná význam těch slov, ale ona prostě s ním potřebuje dělat to skloňování, ten systém... přesto nejede vlak, protože ona ho potřebuje oznámkovat. Říká mi, že ji přece nebudu zkoušet $\mathrm{v}$ osmé tř́dě z vyjmenovaných slov, dyt' je to trapný. No a já tý učitelce říkám: „Ale dyt' ona je neumí! Pro ni je to tak nová a tak těžká látka.“ Takže s některými kolegyněmi je to těžší. 
Učitelky, jako je Petra (ŠC), které se věnují doučování dětí-cizinců, se potom k př́ístupu některých kolegyň a kolegů vyjadřují velmi kriticky. Očekávají totiž i od ostatních, že budou mít chápající a podporující přístup k cizincủm. Pokud to tak není, často je otřesena vlastní self-efficacy učitelů, jelikož spolupráce s kolegy a jejich podpora je pro učitele důležitá. Jinak se cítí ve svých snahách pomoci cizincům osamocení.

\section{Zapojení rodičů-cizinců do školního dění}

Stále častěji se objevují výzkumy dokladující, že míra komunikace školy s rodiči je klíčová pro školní prospěch dětí (Kocayörük, 2016; Gavora \& Majerčíková, 2012; Gustafson \& Rodes, 2006; Epstein et al., 2002). 0 komunikaci s rodiči-cizinci, přicházejícími z více či méně kulturně odlišného prostředí, to platí snad dvojnásobně. Učitelé vykazující větší míru self-efficacy jsou aktivnější v komunikaci s rodiči-cizinci a nenechají se odradit při prvních neúspěších.

V analýze rozhovorů jsme se soustředily na to, jak se učitelé snaží s rodičicizinci komunikovat, jak se snaží zapojovat je do školního dění a jak moc je pro ně komunikace s rodiči-cizinci klíčová. Část učitelů považuje komunikaci s rodiči-cizinci za svou zodpovědnost, zatímco někteří iniciativu nechávají na rodičích. Standa (ŠA) se řadí mezi učitele, kteří nechávají iniciativu při komunikaci zcela na rodičích:

Mám rodiče, který jsou tu furt, mám rodiče, který jsou na telefonu, a mám rodiče, které jsem viděl poprvé, když přivedli dítě, a pak už ne. Někteří vidíte, že mají zájem, aby se děti naučily češtinu, někteří posílají děti do školy proto, že prostě musí, když bydlí na území České republiky, ale vlastně jim na tom vůbec nezáleží. Prostě chrlí do nich čínštinu a chtějí, aby uměli čínsky, sami ti rodiče, žijí na našem území deset patnáct let a nebyli vlastně schopni se naučit základní fráze česky. Protože jsou v té své komunitě čínské a nemají zájem, s tím já nic neudělám.

Učitelka Martina (ŠB) se o komunikaci s rodiči-cizinci aktivně snaží, je pro ni důležitá a nevzdává se při prvním neúspěšném kontaktu, uvedla následující:

Prostě jsem na začátku řekla tatínkovi: „Podívejte se, já vám pomůžu, ale musíte spolupracovat, jinak to nepůjde." S tím tátou v podstatě spolupracujeme, ze začátku jsem ho měla každej tejden ve škole. Z mojí iniciativy. Já jsem prostě chtěla. Vždycky jsem mu napsala, kdy potřebuju, aby přišel, jestli se mu to nehodí, at' vymyslí jiný termín, ale vážně každej tejden chodil a vždycky s nějakým překladatelem nebo překladatelkou. Věřím, že díky tý spolupráci s tatínkem a s tím překladatelem, 
jsme to společnejma silama zlomili, začalo se to prostě všechno vylepšovat. Tak krucinál, dyt' je to o tom dítěti a musíme se snažit společně.

Marie (ŠA) aktivně přijímá zodpovědnost za komunikaci s rodiči-cizinci. Mrzí ji ale, že se rodiče často vymlouvají na neznalost češtiny a odůvodňují tím to, že nepomáhají dětem s povinnostmi do školy:

Ti, kteří neumí česky, to berou jako: To at’ si vyřeší ve škole, já ti nemůžu pomoct. A přitom je to matematika třeba, psaní do sloupečků, co se týká první tř́dy. Nebo jenom rozstř́hat písmenka, jak mají ti prvňáčci. No a my jsme měli na začátku roku schůzku pro ty rodiče, kde jsme jim vysvětlili, jak to bude fungovat, co po nich chceme. A v podstatě děti jsou neštastný, protože maminka neumí česky, tak to s nima neudělá. Maminka dojde, pozvu si ji do třídy, kýve, ano, ano... A stejně to není hotový. Děti jsou potom tady neštastné, že tu pomůcku nemají, že maminka řekla, že neumí česky. A pořád dokola to tak je. Jako kdyby se na to vymlouvali.

Marie (ŠA) si ovšem podle svých slov vede dobře a umí si v takových situacích poradit, často je v kontaktu s rodiči, a pokud nastane problém mezi dětmi, řeší ho přímo s rodiči. Několikrát byla při řešení konfliktů úspěšná, proto věří, že při opakování takové situace se bude úspěch opakovat.

Všichni dotazovaní učitelé se shodli na tom, že komunikace s rodiči-cizinci ze vzdálených kultur je obecně nejnáročnější:

Strašná komunikace s těmi rodiči většinou. Ne jenom že neumí česky, ale spousta rodičů nechce, nezajímá se... Je jim to jedno, co se děje ve škole. Já mám pocit, že ve spoustě př́padů vůbec nic nefunguje, volání, e-maily, občas pak už zafunguje, když to jde přes sociálku, ale to už je extrém. Myslím si, že spousta rodičů vůbec neví, co od nich se vlastně čeká, jo, vůči tý škole a tím, že nekomunikují, tak se to ani nedozvědí. Karla (ŠB)

Učitelé ze špatné komunikace s rodiči-cizinci viní zejména jejich jazykovou bariéru a malé povědomí o českém vzdělávacím systému:

Možná, kdyby na začátku dostali nějakej přehled, co musí, co se od nich očekává, ideálně v jejich jazyce, aby to nebylo česky. Prostě informace typu, že v Čechách jsou třídní schůzky, proto to a to, řeší se tam tohle, nebo že musí nebo měli by kontrolovat žákovskou knížku, notýsek, že děti píšou domácí úkoly. Nějaký vysvětlení, protože hodně $\mathrm{z}$ nich $\mathrm{v}$ tom tápe a těžko se jim to vysvětluje, protože nerozumí... Většinou. (Karla, ŠB) 
Učitelé nemají kapacitu poskytovat tyto informace každému rodiči zvlášt', navíc když čelí jazykové bariéře v komunikaci s rodiči-cizinci. Jedná se ovšem $\mathrm{z}$ pohledu učitelů o zásadní věc a to, aby byla škola a rodina ve shodě.

\subsection{Když učitele při výuce cizinců doprovází všudypř́tomné obavy...}

Při analýze rozhovorů se ukázalo, že významnou roli v učitelské self-efficacy hrají různorodé obavy ze samotné přítomnosti dětí-cizinců ve třídě pramenící $\mathrm{z}$ malé zkušenosti učitelů s touto skupinou žáků a nedůvěrou ve své schopnosti, jak je zapojit do výuky v rámci běžné tř́ídy. Obavy byly protkané všemi rozhovory. Rozhodly jsme se proto druhou oblast prezentace výsledků věnovat tomu, čeho konkrétně se učitelé při výuce dětí-cizinců obávají a co jinými slovy oslabuje jejich self-efficacy.

\section{Výuka dětí-cizinců s nulovou znalostí češtiny}

Největší obavu učitelů z řad respondentů vyvolává výuka dětí přicházejících do běžných tříd s nulovou znalostí češtiny. Učitelé totiž postrádají základní informace o tom, jak pracovat s dětmi, které nerozumí vyučovacímu jazyku, v běžné třídě. Nakonec je to vždy na konkrétním učiteli, jak se se situací vypořádá. Kromě první třídy, v níž učitel může postupovat se všemi dětmi stejně (protože všechny se učí psát a číst od začátku), se učitelé shodli, že mají dvě možnosti, jak k dané situaci přistoupit. Takového dítěte si mohou bud'to nevšímat a využít možnosti ho neklasifikovat, nebo pakliže učitel vykazuje vyšší míru self-efficacy, pro něj vytvořit materiály, které by mohlo být schopno používat i bez znalosti češtiny:

Dnes je to takový, že vás nikdo nekontroluje, takže je možnost, že já je z češtiny nemusím hodnotit, takže klidně můžu ř́íct, at' si kreslí, at' sedí a poslouchá. To je jedna možnost, neřešíte je! Potom ale by bylo, že jim musíte dát známku z nějaké prrírodovědy, vlastivědy, to jsme ale odsuzovali a pořád jsme ř́́kali: dyt' to je ještě horší, tam jsou ještě speciální výrazy... Takže se nakonec řeklo, že všude, kde se ten jazyk odráží, takže v podstatě kromě nějaký výtvarky, pracáku, těláku máte možnost ji všude neoklasifikovat. A když teda ten učitel se umí vcítit do toho žáka, tak jdete a dáte jim něco... No, tak když ona mi přišla, tak já jsem jí dala nějaký pracovní sešit, že jsem si šla pro vyřazený pracovní sešity, které se už nepoužívají, ale skladujeme je... Vzala jsem si něco, co by mohla dělat $\mathrm{z}$ tý češtiny... Z tý matiky... Chytá se, ona to umí spočítat, ale neumí to říkat, ona to číslo neumí nazvat, takže většinou mi na tu číslici ukáže, pak třeba to řeknu nahlas. (Helena, ŠC) 
Učitelé považují stávající situaci, v níž jim do třídy přicházejí děti bez znalosti češtiny, za systémově nedořešenou a dlouhodobě neudržitelnou.

My se samozřejmě snažit můžeme... Ale není to vždycky úplně jednoduché, skutečně a učitel, když tam má vždycky skoro těch třicet dětí ve tř́dě, tak samozřejmě těch dalších 29 dětí trošku strádá, takže myslím si, že by ty cizinci měli přijít do školy s určitou znalostí českého jazyka, a to si myslím, že by bylo potřeba jako nějakým způsobem opravdu dořešit. (Simon ŠC)

Učitelé tak vypovídali, že jejich self-efficacy je narušována tím, že systémové nastavení vzdělávání dětí-cizinců nepovažují za dostatečné.

\section{Kontakt s cizinci ze vzdálených kultur}

Další obava, která vyplynula z šetření, je výuka dětí-cizinců z odlišných kultur a styk s jejich rodiči. Jedná se zejména o obavu z kontaktu s muslimskými rodinami, a to především u těch učitelů, kteří ještě žádnou osobní zkušenost s muslimy nemají:

Žáci se tu nestraní těm novým ani noví se nestraní našim žákům. Neumím si představit, jak by to ale vypadalo s muslimským dítětem. Co nezažiješ, nevíš. Nechci úplně generalizovat, tolik zkušeností nemám, ale přijde mi, že slovanský národy a Vietnamci se $\mathrm{k}$ nám začleňujou bez problémů. Ono se to nerado slyší, ale dovedu si představit, že muslimka v šátku by mohla být problém. (Sylva, ŠB)

I ostatní učitelé uváděli poněkud stereotypně, že některé národnosti se začleňují lépe než jiné a je s nimi snazší práce než s jinými. Za lépe začlenitelné považují učitelé slovanské národy kvůli jejich kulturní i jazykové blízkosti. Právě jejich kulturní a jazyková blízkost $\mathrm{v}$ učitelích vyvolává pocit, že s takovými dětmi uspějí, protože jim jsou bližší. Naopak učitelé uváděli, že si především vůči arabským rodinám vybudovali za dobu své praxe nezáměrně určité stereotypy, které jim brání v př́ístupu k dětem ze vzdálených kultur a kvůli kterým si v jejich výuce př́liš nevěří a někteří mají tendence se jim spíše vyhýbat - jako na př́íklad Standa (ŠA):

Slovanské země, tak samozřejmě $s$ těma dětma se lépe pracuje, je to $v$ pohodě. Jsem ale docela otřesen tím arabským hochem, jo, to jsem jako nějak nedokázal splynout s jeho duší a jeho myšlením a cítím, že ta odlišnost je prostě natolik velká. Ten hoch je nadaný, inteligentní, ale prostě je veden způsobem, který já nechápu, nerozumím mu... A jako to, abych ho přiměl $k$ tomu, aby respektoval ty pravidla, která máme tady, tak je to, jak říkám, skoro až nadlidský výkon mi to tak připadá, jo. Navíc já ho nemám učit zavazovat tkaničky, učit ho smrkat, učit ho základním 
hygienickým návykům, jak si poskládat věci, že když si je rozháže, tak že si je musí zvednout zase on sám, že neexistuje kouzlo, kterým se dostanou zpět do aktovky a podobně. Přitom, že je učíte tyhlety základní věci, tak je máte učit ještě vlastně číst, psát a počítat. (...). No a kvůli zkušenosti s tímto chlapcem vím, že pokud přijde někdo takový další, tak se budu snažit, abych ho nedostal do třídy já.

Učitelé cítí, že se často ocitají v situaci, ve které nechtějí být, která jim přináší práci navíc a kterou jako učitelé základní školy nemají v popisu práce. Přináší jim tak starosti navíc, protože jsou často ve svém snažení spíše neúspěšní. Zmíněné souvisí s hodnotami a kulturou dané rodiny a s tím, že rodiče-cizinci často ani nevědí, co se od nich a od dítěte v českých základních školách očekává, což opět souvisí s výše zmíněnou důležitostí komunikace rodičů a školy.

\section{Nedostatečné systémové znalosti o výuce dètí-cizinců}

Jelikož žádný z našich respondentů neprošel kurzem zaměřujícím se na vzdělávání cizinců $\mathrm{v}$ rámci svých studií na vysoké škole, s dětmi-cizinci se setkali poprvé až po několikaleté praxi, provází je po celou dobu pocit toho, že vlastně nevědí, jak s dětmi-cizinci pracovat, a jejich výuka probíhá především intuitivně a záleží čistě na osobním nastavení učitelů, kolik energie do jejich výuky investují. Nedostatek informací o tom, jak přistupovat k výuce cizinců, vnímají dotazovaní učitelé jako další obavu, která jim ubírá na jejich self-efficacy v dané oblasti. Informace o tom, jaké způsoby jsou při výuce cizinců vhodné, se snaží získat především dvěma způsoby. Prvním z nich jsou doplňující semináře či kurzy, ke kterým jsou však učitelé skeptičtí, a to především kvůli obsahové náplni dílčích kurzů. Učitelé se shodovali, že nabízené kurzy a školení jsou zaměřeny většinou pouze na jazykovou podporu dětí-cizinců, nikoli na práci s cizinci jako takovou. Školení dále nebývají rozlišena podle věku dítěte, což je podle učitelů velký nedostatek. Celkově učitelé postrádají praktičnost v nabízených kurzech. Petra (ŠC) uvedla:

Když sem začalo přicházet čím dál víc cizinců, našla jsem e-learningovej půlroční kurz pro vyučující češtiny pro cizince. No nevím, asi jsem měla velký očekávání, protože jsem si myslela, že mi někdo poradí praktický věci, protože ted' přijde Afgánec, neumí ani pozdravit, tak jsem čekala, že mi řeknou, co ted', co potom a tak. Jak vysvětlovat skloňování, gramatiku. No neporadil, $v$ tom je právě prý ta krása tady toho oboru, že si to jako každý vymyslí sám (smích), mi ř́kala paní lektorka, takže ve výsledku já už jsem pak rezignovala úplně na všechno. Já bych teda chtěla, kdyby poslali seshora nějakou metodiku, protože my prostě nevíme a vaříme $\mathrm{z}$ vody. 
Učitelé by ocenili lepší nabídku vzdělávacích kurzů, seminářů či školení, které v současné době nereflektují jejich potřeby a nezískávají na nich informace, díky kterým by se přenesly přes své obavy a zvýšili tak své self-efficacy. Učitelé by především ocenili informace o výuce dětí-cizinců z kulturně odlišného prostředí a rady týkající se př́ístupu k těmto kulturám, což navazuje na výše prezentovaný pocit nejistoty z výuky dětí-cizinců $\mathrm{z}$ kulturně odlišného prostředí:

Potřebovala bych vědět, $\mathrm{z}$ jaké země ty děti pochází a na co já můžu narazit a co si $\mathrm{k}$ těm dětem můžu dovolit. Pokud mi přijde někdo z arabských zemí, tak potřebuju vědět, jestli mám nějaký omezení, protože samozřejmě ze svý pozice chci, aby to dítě dělalo všechno, co dělají ostatní děti, protože ale nevím, jestli mají nějaké náboženské omezení nebo kulturní omezení, no a pokud to budu po tom dítěti vyžadovat, tak samožrejmě se můžu dostat do konfliktu, a tomu se chci vyhnout. Takže by určitě bylo dobrý už ted'ka seznámit učitele právě s... nevim, jak to říct... $\mathrm{s}$ národnostmi, které $\mathrm{k}$ nám přicházejí, a co to s sebou nese. S čím se můžeme setkat. (...) To je to, čeho se třeba bojím jakoby do budoucna, že když mi přijde do tř́ídy někdo, kdo nebude chtít se přizpůsobit, tak potom si nejsem jistá, jestli jsem připravená na to, to řešit. (Sabina, ŠB)

Vzhledem ke zmíněné skepsi učitelů vůči nabízeným kurzům se dotazovaní učitelé uchylují častěji ke druhému způsobu, jak získat potřebné informace, a tím je sdílení zkušeností s ostatními kolegy:

Na internetu se dívám na názory učitelů, jezdím po sešlostech učitelů češtiny jako cizího jazyka, kde řeknu svoje zkušenosti, ale hlavně pro mě je důležitý, že získám informace od ostatních učitelů a můžu se poučit a dozvím se, jak se s tím vypořádávají jinde. (Marie, ŠA)

Taková setkání jsou učiteli velmi oceňovaná především z důvodu, že se na nich dozví praktické informace, rady a zkušenosti ostatních. Výpověd' dále odkazuje na důležitost kolegiální podpory pro pocit vyšší self-efficacy.

\section{Závěr a diskuse}

Předložená studie se zabývala tématem učitelské self-efficacy při práci s dětmi-cizinci. Na to, jak ji dotazovaní učitelé vnímají, jsme se dívaly optikou sedmi oblastí, ve kterých dle odborné literatury excelují učitelé s vysokou mírou self-efficacy, a dále optikou základních aspektů, které dle respondentů ovlivňují jejich self-efficacy. 
Obecně by se dalo říci, že na úroveň self-efficacy dotazovaných učitelů mají vliv především dosavadní zkušenosti v práci s dětmi-cizinci, dále nastavení systému a v neposlední řadě osobnostní charakteristiky samotných učitelů. Když učitel ví, že podobné problémy už řešil (a vyřešil), posiluje to jeho důvěru ve zvládnutí dalších. Když je celkově otevřený, empatický, trpělivý a svou práci bere jako poslání, k překážkám v podobě obtíží při práci s dětmi-cizinci přistupuje jako k výzvám, což svědčí o vysoké míře self-efficacy. Pokud učitel nemá ani dobré zkušenosti s cizinci ani vhodné osobní nastavení, pak se sám staví na předem prohranou pozici. Všechny dotazované spojuje jejich kritický pohled na „systémové překážky“, jako jsou počet dětí ve třídě či nedostatky v hlavním vzdělávacím proudu, kvủli kterým učitelé často zastaví své snahy věnovat se dětem-cizincům intenzivněji.

Předností exploračních studií bývá to, že ve zkoumané oblasti dovolují odkrýt nové aspekty zkoumané problematiky. Na základě výsledků naší analýzy bychom rády zdůraznily dva:

1) Text poukázal na možnost využitelnosti sedmi charakteristik učitele s vysokým self-efficacy jako nástroje pro popis a další zkoumání tohoto jevu $\mathrm{v}$ českém prostředí. Učitelé totiž ve svých výpovědích spontánně a s přehledem pokryli tematický rozsah charakteristik učitele s vysokou učitelskou self-efficacy sestavených na základě závěrů několika autorů zabývajících se touto problematikou. To svědčí o tom, že se $\mathrm{v}$ žádném případě nejedná o umělé konstrukty nevycházející z praxe učitelů.

2) Text odkryl komplexnost pohledů učitelů na svou self-efficacy. Dotazovaní vnímali širokou škálu faktorů, které ovlivňují jejich učitelskou self-efficacy, a uváděli vlastní konkrétní nápady na posílení své stávající selfefficacy. Prezentované závěry tak otevírají další možnosti zkoumaní jak samotného konstruktu učitelské self-efficacy, tak konkrétně self-efficacy českých učitelů při práci s dětmi-cizinci.

Explorační studie s malým množstvím případů neumožňuje jednoznačnou generalizaci a ani se o ni nepokoušíme. Rády bychom ale podotkly, že výsledky této studie se $\mathrm{v}$ mnohém shodují s výsledky dosavadních zahraničních a českých výzkumů v př́buzných oblastech. I na našem malém vzorku se ukázalo, že běžné učitelské postupy aplikované ve třídách $\mathrm{s}$ cizinci často selhávají (Jenks, Lee, \& Kanpol, 2001; Yeo, 1997; Nieto, 1996; Kanpol \& McLaren, 1995; Sleeter, 1992). Učitelé nevědí, jaké vyučovací postupy by 
měli v kulturně heterogenních třídách aplikovat, chybí jím potřebné znalosti (Leix \& Záleská, 2017; Kitsantas \& Mason, 2012; Banks, 1991, 1996). Dotazovaní učitelé mají dále potíž pracovat s časem tak, aby se cizincům mohli věnovat $v$ rámci běžné výuky, což odkazuje na jejich nízkou self-efficacy. Schopnost pracovat $\mathrm{s}$ časem je totiž jedna $\mathrm{z}$ charakteristik učitele s vysokou mírou self-efficacy (Gibson \& Dembo, 1984). Dotazovaní učitelé se tak nejčastěji uchylují k určení tak zvaného patrona z řad spolužáků (Průcha, 2006), který je cizincům k dispozici.

Stejně jako ve výzkumu Howarda (1999) se i zde ukázalo, že nedostatečná teoretická průprava učitelů o výuce dětí-cizinců způsobuje $v$ praxi jejich časté obavy a nedůvěru v sebe sama. Obavy $\mathrm{z}$ výuky dětí-cizinců vyvěrají často z nejistoty, zda a jak ve výuce reagovat na etnicitu a kulturní rozdílnost žáků. Také naše výsledky nastínily, že za příčinami obav učitelů stojí často jejich rasové/národnostní předsudky, úzkost z nedostatku znalostí o etnické a kulturní rozmanitosti.

Vzhledem k výše uvedenému se nabízí otázka, jakým způsobem lze self-efficacy učitelů pro práci s dětmi-cizinci posílit. Rády bychom se vyhnuly moralizování a teoretizování, proto zde využijeme toho, že dotazovaní učitelé sami spontánně uváděli návrhy, které by jim ulehčily od nejistot a pomohly cítit se jistější při výuce dětí-cizinců.

Prvním bodem, který se na základě výpovědí učitelů jeví jako klíčový, je reakce na přítomnost dětí-cizinců s nulovou znalostí češtiny v běžné třídě. Učitelé by ocenili pomoc zvenčí, a to především zřízením přípravných tříd pro děti-cizince, které by po určitou dobu měly pouze jazykovou přípravu, než by byly zařazené do běžné tř́́dy. Učitelé věří, že děti-cizince, které mají alespoň základní znalost češtiny, by do své výuky mnohem lépe zapojili a mnohem více by věděli, jak s takovými dětmi pracovat.

Také druhá oblast vyplývá z potřeby externí pomoci. Jedná se konkrétně o další vzdělávání pedagogických pracovníkủ. Učitelé věří, že lepší informovanost o odlišných kulturách, jejich zvycích a hodnotách, by zmírnila jejich obavy z výuky dětí-cizinců a z kontaktu s jejich rodiči; je ostatně obecně známo, že největší obavy máme $\mathrm{z}$ toho, co neznáme. Učitelé nejsou spokojení s nabídkou seminářů, kurzů a školení a uvádějí oblasti, které by ocenili nabídce: jedná se především o výuku jiných předmětů než češtiny pro děti-cizince, praktické rady o způsobech výuky dětí-cizinců, zásady řešení 
konfliktů založených na etnické či rasové nesnášenlivosti a specifika různých kultur a interkulturní komunikaci. ${ }^{14}$

Poslední oblastí, kvůli které jsou učitelé ve své práci nejistí, je nízká informovanost rodičů-cizinců o českém školství; ocenili by, aby rodiče ještě před příchodem do školy znali své povinnosti a očekávání ze strany školy. Vzhledem $\mathrm{k}$ počtu dětí $\mathrm{v}$ českých třídách základních škol respondenti zmiňovali také potřebu zdatných asistentů pedagoga, a/nebo snížení počtu dětí ve třídách.

Učitelé jistě vyžadují systémovou podporu, ale ta samotná nestačí. Klíčové je rovněž nastavení učitelů, které vyvěrá z jejich osobnostních charakteristik. Studii proto uzavíráme výpovědí jedné z učitelek (Sabina, ŠB), která názorně vystihuje práci s žáky-cizinci pohledem jedné ze zásadních složek (nejen) učitelské self-efficacy: „Je to pro toho, kdo rád poznává, kdo se nebojí něčeho jiného, kdo to bere jako výzvu. Je to pro toho, kdo nebude říkat: Ono to nejde, ale bude hledat cestu, jak to jde!“.

\section{Literatura}

Anthony, T., \& Kritsonis, W. (2007). A mixed methods assessment of the effectiveness of strategic e-mentoring in improving the self-efficacy and persistence (or retention) of alternatively certified novice teachers within an inner city school. District Doctoral Forum National Journal for Publishing and Monitoring Doctoral Student Research, 4(1), 1-8.

Adams, M., \& Bell, L. A. (Eds.). (2016). Teaching for diversity and social justice. Londýn: Routledge.

Ashton, P. T., \& Webb, R. B. (1986). Making a difference: Teachers' sense of efficacy and student achievement. New York: Longman.

Bačáková, M. (2012). Vzdělávání dětí-uprchlíků: podpora nabízená základními školami v Norsku a ČR. Orbis Scholae, 6(1), 81-93.

Bandura, A. (1986). Social foundations of thought and action: A social cognitive theory. Englewood Cliffs: Prentice-Hall.

Bandura, A. (1995). Self-efficacy in societies. New York: Cambridge University Press.

Bandura, A. (1997). Self-efficacy: Toward a unifying theory of behavioral change. Psychological Review, 84(2), 191-215.

Bandura, A. (2005). Evolution of social cognitive theory. In K. G. Smith \& M. A. Hitt (Eds.), Great minds in management (s. 9-35). Oxford: Oxford University Press.

Banks, J. (1991). A curriculum for empowerment, action, and change. In C. E. Sleeter (Ed.), Empowerment through multicultural education (s. 125-141). Albany: State University of New York Press.

14 Nutnost posilnění vzdělávání učitelů v oblasti vzdělávání cizinců reflektují rovněž evropské dokumenty (The Council of the European Union, 2009; Hice, 2004). 
Banks, J. (1996). The historical reconstruction of knowledge about race: Implications for transformative teaching. In J. A. Banks (Ed.), Multicultural education, transformative knowledge, and action: Historical and contemporary perspectives (s. 64-87). New York: Teachers College Press.

Bennett, C. I. (1995). Preparing teachers for cultural diversity and national standards of academic excellence. Journal of Teacher Education, 46, 259-265.

Boyatzis, R. (1998). Qualitative information: Thematic analysis and code development. Thousand Oaks: Sage.

Carara, G., Barbaranelli, C., Steca, P., \& Malone, P. (2006). Teachers' self-efficacy beliefs as determinants of job satisfaction and students' academic achievement: A study at the school level. Journal of School Psychology, 44(1), 473-490.

Creswell, J. D. (2014). Research design. Qualitative, quantitative and mixed methods approaches. Los Angeles: Sage.

Cuthill, M. (2002). Exploratory research: Citizen participation, local government, and sustainable development in australia. Sustainable Development, 10(2), 79-89.

ČSÚ. (2015). Děti, žáci a studenti podle státního občanství v mateřských školách, základních, středních a vyšších odborných školách a konzervatořích ve školním roce 2014/15. Praha: Ministerstvo školství, mládeže a tělovýchovy. Dostupné z https://www.czso.cz/csu/ czso/4-vzdelavani-cizincu

Darling-Hammond, L., Chung, R., \& Frelow, F. (2002). Variation in teacher preparation: How well do different pathways prepare teachers to teach? Journal of Teacher Education, 53(4), 286-302.

Epstein, J., Sanders, M., Simons, B., Salinas, K., Jansorn, N., \& van Voorhis, F. (2002). School, family and community partnerships. Your handbook for action. Thousand Oaks: Corwin Press.

Eurydice. (2004). Integrating immigrant children into schools in Europe. Brussels: Eurydice.

Eurydice. (2009). Integrating immigrant children into schools in Europe. Brussels: Eurydice.

Gavora, P. (2010). Slovak pre-service teacher self-efficacy: Theoretical and research considerations. The New Educational Review, 21(2), 17-30.

Gavora, P., \& Majerčíková, J. (2012). Vnímaná zdatnost' (self-efficacy) učitela: oblast' vyučovania a oblast' spolupráce s rodičmi. Pedagogicka orientace, 22(2), 205-221.

Gibson, S., \& Dembo, M. H. (1984). Teacher efficacy: A construct validation. Journal of Educational Psychology, 76(4), 569-582.

Goddard, R. D., \& Woolfolk Hoy, A. (2000). Collective teacher efficacy: Its meaning, measure, and impact on student achievement. American Educational Research Journal, 37(2), 479-507.

Grant, C. E., \& Sleeter, C. E. (2008). Making choices for multicultural education: Five approaches to race, class, and gender. Michigan: J. Wiley \& Sons.

Gürsoy, A., \& Akyniyazov, M. (2016). Teachers' sense of self-efficacy and attitudes towards multicultural education regarding an out-of school activity. Romanian Journal of Experimental Applied Psychology, 7(3), 37-55.

Guskey, T. R. (1988). Teacher efficacy, self-concept, and attitudes toward the implementation of instructional innovation. Teaching and Teacher Education, 4(1), 63-69.

Gustafson, S. L., \& Rodes, R. E. (2006). Parental correlates of physical activity in children and early adolescents. Sports Medicine, 36(1), 79-97. 
Guyton, E. M, \& Wesche, M. V. (2005). The multicultural efficacy scale: Development, item selection, and reliability. Multicultural Perspectives, 7(4), 21-29.

Heading, G., \& Traynor, V. (2005) Analyzing qualitative data - coding. Dostupné z http://www. nswphc.unsw.edu.au/pdf/

Hendl, J. (2005). Kvalitativní výzkum: základní metody a aplikace. Praha: Portál.

Henson, R. K. (2001, leden). Teacher self-efficacy: Substantive implications and measurement dilemmas. Plenární přednáška prezentovaná na Educational Research Exchange, Texas A\&M University, Texas. Dostupné z https://www.uky.edu/ eushe2/Pajares/EREkeynote. PDF

Hoskovcová, S. (2005). Self-efficacy: důvěra dítěte ve vlastní schopnosti. Psychologie dnes, 11(7-8), 35-37.

Howard, G. (1999). We can't teach what we don't know: White teachers, multiracial schools. New York: Teachers' College Press.

Hrbáčková, K., \& Šafránková, A. P. (2015). Vnímání vlastní účinnosti pedagogických pracovníků v oblasti institucionální péče o děti a mládež. Sociální pedagogika, 3(2), 9-24.

Janská, E., Průšvicová, A., \& Čermák, Z. (2011). Možnosti výzkumu integrace dětí Vietnamců v Česku: př́klad základní školy Praha-Kunratice. Geografie, 4, 480-496.

Jarkovská, L., Lišková, K., Obrovská, J., \& Souralová, A. (2015). Etnická rozmanitost ve škole. Stejnost v různosti. Praha: Portál.

Jefferson, A. P. (2013). An exploration of preservice teachers' multicultural self-efficacy and awareness of white privilege. Doctoral dissertation. Ypsilanti: Eastern Michigan University. Dostupné z http://commons.emich.edu/theses/591

Jenks, C., Lee, J. O., \& Kanpol, B. (2001). Approaches to multicultural education in preservice teacher education: Philosophical frameworks and models for teaching. Urban Review, 33(2), 87-105.

Kanpol, B., \& McLaren, P. (1995). Critical multiculturalism. Uncommon voices in a common struggle. London: Bergin \& Garvey.

Kitsantas P., \& Mason, G. (2012). Teacher efficacy scale for classroom diversity (TESCD): A validation study. Profesorado. Revista de currículum y formación del profesorado, 16(1), 35-44.

Klassen, D. H. (2004). Gestures in African oral narrative. In P. M. Peek \& Kwesi Yankah (Eds.), African folklore: An encyclopedia (s. 298-303). New York/London: Routledge.

Kocayörük, E. (2016). Parental involvement and school achievement. International Journal of Human Behavioral Science, 2(2), 1-7.

Komori, M. (nedatováno). Thematic analysis. Dostupné z http://designresearchtechniques.com/ casestudies/thematic-analysis/

Kostelecká, Y., Kostelecký, T., Vodičková, K., \& Jančařík, A. (2015). Linguistic integration of middle school immigrant children in Czechia. AUC Geographica, 50(2), 181-192.

Kostelecká, Y., Hána, D., \& Hasman, J. (2017). Integrace žáků-cizinců v širším kontextu. Praha: Pedagogická fakulta Univerzity Karlovy.

Leix, A. (2015). No prejudice-free society means no prejudice-free teachers, but better times are coming: Teachers and cultural diversity. Human Affairs: Postdisciplinary Humanities and Social Sciences Quarterly, 25(3), 302-316. 
Leix, A. (2017). Cizinec ve tř́dě, k tomu možná dyslektik? Nojo, to bude mazec! In L. Doleží (Ed.), Specifické poruchy učení a čeština jako druhý/cizí jazyk. Př́ručka pro lektorky a lektory (s. 56-63). Praha: AUČČJ.

Leix, A., \& Záleská, K. (2017). Teachers' experiences with immigrant children in Czech elementary schools. Human affairs, 27(1), 30-47.

Machovcová, K. (2017). Czech elementary school teachers' implicit expectations from migrant children. International Journal of Educational Development, 53, 92-100.

McAllister, G., \& Irvine, J. J. (2000). Cross cultural competency and multicultural teacher education. Review of Educational Research, 70(1), 3-24.

Merten, K. (1996). Inhaltsanalyse. Einführung in Theorie, Methode und Praxis. Opladen: Westdeutscher Verlag.

META. (2014). Vzdělávání a začleňování žáků s odlišným mateřským jazykem. Systémová doporučení. Praha: META, o.p.s.

Moore, N. (2007). (Re)Using qualitative data. Sociological Research Online, 13(3), 1-13.

MŠMT. (2012). Informace o vzdělávání cizinců na území ČR pro krajské úřady a základní školy. Dostupné z http://www.msmt.cz/vzdelavani/zakladni-vzdelavani/informace-ovzdelavani-cizincu-na-uzemi-cr-pro-krajske-urady

Nieto, S. (1996). Affirming diversity: The sociopolitical context of multicultural education. New York: Longman.

Nieto, S. (2000). Some thoughts on transforming teacher education for a new century. Journal of Teacher Education, 51(3), 182-187.

Nolen, S. B., Ward, C., Horn, I. S., Campbell, S., Mahna, K., \& Childers, S. (2007). Motivation to learn during student teaching. Dostupné z http://faculty.washington.edu/sunolen/motsem/ AERA\%202007\%20-\%20Nolen\%20et\%20al.pdf

Peguero, A. A., \& Bondy, J. M. (2011). Immigration and students' relationship with teachers. Education and Urban Society, 43(2), 165-183.

Průcha, J. (2006). Srovnávací pedagogika. Praha: Portál.

Ross, J. A., \& Bruce, C. D. (2007). Professional development effects on teacher efficacy: Results of randomized field trial. Journal of Educational Research, 101(1), 50-60.

Schreier, M. (2012). Qualitative content analysis in practice. London: Sage.

Silverman, D. (2005). Doing qualitative research: A practical handbook. Thousand Oaks: SAGE.

Silverman, S. K. (2008). The teachers' sense of multicultural efficacy scale: Construction and validation. Dostupné $\mathrm{z}$ https://pdfs.semanticscholar.org/6d3f/ f49cf61e7efc06fd1a4f256a2a2c313bfa0e.pdf

Sleeter, C. E. (1992). Restructuring schools for multicultural education. Journal of Teacher Education, 43(2), 141-148.

Sleeter, C. E. (2008). Equity, democracy, and neoliberal assaults on teacher education. Teaching and Teacher Education, 24(8), 1947-1957.

SOZE (2013). Sdružení občanů zabývajících se emigranty. Výroční zpráva 2013. Dostupné z http://www.soze.cz/wp/wp-content/storage/Vyrocni_zprava_2013.pdf

Stake, R. E. (2005). Qualitative Case Studies. In N. K. Denzin \& Y. S. Lincoln (Eds.), The Sage handbook of qualitative research (s. 443-466). Thousand Oaks: Sage.

Strauss, A. L., \& Corbinová, J. (1999). Základy kvalitativního výzkumu: postupy a techniky metody zakotvené teorie. Boskovice: Albert. 
Streb, C. K. (2002). Exploratory case study. In A. J. Mills, G. Durepos, \& E. Wiebe (Eds.), Encyclopedia of case study research (s. 372-374). Thousand Oaks: Sage.

Švaříček, R., Šed'ová, K., Janík, T., Kaščák, O., Miková, M., Nedbálková, K. ... Zounek, J. (2007). Kvalitativní výzkum v pedagogických vědách. Praha: Portál.

The Council of the European Union. (2009). Council conclusions of 12 May 2009 on the strategic framework for European cooperation in education and training ('ET 2020'). Official Journal of the European Union, C119/2. Dostupné z http://eur-lex.europa.eu/legal-content/EN/ ALL/?uri=celex:52009XG0528(01)

Titone, C. (1998). Educating the white teacher as ally. In J. L. Kincheloe, S.-R. Steinberg, N. M. Rodriguez, \& R. G. Chennault (Eds.), White reign: Deploying whiteness in America (s. 159-174). New York: St. Martin's Griffin.

Tschannen-Moran, M., \& Woolfolk Hoy, A. (2001). Teacher efficacy: Capturing an elusive construct. Teaching and Teacher Education, 17(7), 783-805.

United Nations (2017). International migrant stock: The 2017 revision. Dostupné z http://www. un.org/en/development/desa/population/migration/data/estimates2/estimates17. shtml

Urbánek, T., \& Čermák, I. (1997). Vliv self-efficacy na agresi a depresi u dětí. Československá psychologie: Časopis pro psychologickou teorii a praxi, 3, 193-199.

Vyhláška č. 27/2016 Sb., O vzdělávání žáků se speciálními vzdělávacími potřebami a žáků nadaných. Dostupné z http://www.msmt.cz/dokumenty-3/vyhlaska-c-27-2016-sb-ovzdelavani-zaku-se-specialnimi

Villegas, A. M., \& Lukas, T. (2002). Preparing culturally responsive teachers. rethinking the curriculum. Journal of Teacher Education, 53(1), 20-32.

Watson, S. (1991). A study of the effects of teacher efficacy on academic achievement of third-grade students in selected elementary schools in South Carolina. (Dizertační práce). Orangeburg: South Carolina State College.

Wiegerová, A., Svatoš, T., Pavelková, I., Mareš, J., Hrabal, V., Ficová, L., \& Gavora, P. (2012). Self-efficacy v edukačných súvislostiach. Bratislava: SPN.

Witter, S. (2013). An exploratory study of the policy proces and early implementation of the free NHIS coverage for pregnant women in Ghana. International Journal for Equity in Health, 12(16), 1-11.

Yeo, F. L. (1997). Inner-city schools, multiculturalism, and teacher education: A professional journey. New York: Garland.

Yildirim, S., \& Tezci, E. (2016). Teachers' attitudes, beliefs and self-efficacy about multicultural education: A scale development. Universal Journal of Educational Research, 4(12A), 196-204.

Zákon č. 561/2004 Sb., o předškolním, základním, středním, vyšším odborném a jiném vzdělávání, školský zákon. (2004). Praha: Tiskárna Ministerstva vnitra.

Zákon č. 325/1999 Sb., Zákon o azylu a o změně zákona č. 283/1991 Sb., o Policii České republiky, ve znění pozdějších předpisủ, (zákon o azylu). (1999). Praha: Tiskárna Ministerstva vnitra.

Zulkosky, K. (2009). Self-efficacy: a concept analysis. In Nursing Forum, 44(2), 93-102. 


\title{
Teachers' self-efficacy in immigrant children education in a broader context
}

\begin{abstract}
The presented article deals with the topic of self-efficacy of the Czech elementary school teachers in the immigrant children education. The research question asks: What are the characteristics of teachers' perception of their self-efficacy in immigrant children education? To gain the answer, we have analysed semi-structured interviews with the teachers that have various experience with immigrant children education. During the analysis, we have taken into account the basic characteristics of behaviour of teachers' with high perception of self-efficacy that we have built on the literature reviews. Our survey has shown a number of perceived factors that play a key role in teachers' ability to educate immigrant children. One example is the important role of the level of teachers' experience with immigrant children education. Teachers' concerns about working with immigrant children that have no knowledge of the Czech language and that come from non-traditional cultures, negatively effects their perception of self-efficacy. The respondents highlight possible ways to increase their self-efficacy in the discussed area. The suggestions are for example: to establish preparatory language classes for immigrant children with no knowledge of the Czech language or to strengthen teacher education in the specific areas concerning practical aspects of work in the culturally heterogeneous classes.
\end{abstract}

Key words: teachers' self-efficacy, immigrant children education, teacher assistant, preparatory language classes

\section{Autoři}

Mgr. Klára Záleská, Masarykova univerzita, Filozofická fakulta, Ústav pedagogických věd, Arna Nováka 1/1, 60200 Brno, e-mail: zaleska@phil.muni.cz

Alicja Leix: Nezávislý výzkumník, e-mail: alicjaleix@gmail.com 